\title{
Influence of 2,3-Diphosphoglycerate
}

\section{Metabolism on Sodium-Potassium Permeability}

\author{
in Human Red Blood Cells: Studies with
}

Bisulfite and Other Redox Agents

\author{
John C. PARKER \\ From the Division of Hematology, Department of Medicine, University of \\ North Carolina, Chapel Hill, North Carolina 27514
}

\begin{abstract}
A B S T R A C T It is known that bisulfite ions can selectively deplete red blood cells of 2,3-diphosphoglycerate (2,3-DPG). Studies of the effects of bisulfite on sodiumpotassium permeability and metabolism were undertaken to clarify the physiologic role of the abundant quantities of 2,3-DPG in human erythrocytes. Treatment of cells with bisulfite results in a reversible increase in the passive permeability to $\mathrm{Na}$ and $\mathrm{K}$ ions. Metabolism of glucose to lactate is increased, with a rise in the intracellular ratio of fructose diphosphate to hexose monophosphate. Cell 2,3-DPG is quantitatively converted to pyruvate and inorganic phosphate. The permeability effects of bisulfite are countered by ethacrynic acid and by such oxidizing agents as pyruvate and methylene blue. Taken together, the results suggest that the effects on $\mathrm{Na}-\mathrm{K}$ flux of bisulfite are related more to the reducing potential of this anion than to its capacity to deplete cells of 2,3-DPG.
\end{abstract}

\section{INTRODUCTION}

2,3-DPG ${ }^{1}$ is present in small concentrations in most mammalian tissues, where it functions as a cofactor in the monophosphoglyceromutase reaction $(1,2)$. The existence of relatively large amounts of this compound in the erythrocytes of some mammals, including humans,

Received for publication 20 June 1968 and in revised form 19 September 1968.

1 Abbreviations: ATP $=$ adenosine triphosphate; 2,3-DPG $=2,3$ diphosphoglycerate; G6P = glucose 6-phosphate; FDP $=$ fructose diphosphate; triose- $P=$ the sum of glyceraldehyde 3-phosphate plus dihydroxyacetone phosphate; $3-\mathrm{PG}=$ 3-phosphoglycerate; pyr = pyruvate; lact=lactate; $\mathrm{S}_{2} \mathrm{O}_{5}$ $=$ metabisulfite ion ; $\mathrm{P}_{1}=$ inorganic phosphate; $\mathrm{GSH}$ and $\mathrm{GSSH}=$ reduced and oxidized forms of glutathione. has attracted much attention. Several authors have implicated 2,3-DPG metabolism in the maintenance of ionic equilibria in red blood cells. Guest and Rapoport (3) suggested that 2,3-DPG functions as an adjustable pool of impermeant anions which acts to stabilize cell volume in various pathologic states. Gardos $(4,5)$ has postulated that the permeability of the cell membrane to potassium ions depends on the activity within the cell of 2,3-DPG phosphatase, the enzyme which splits 2,3-DPG into 3-PG and $P_{1}$. Benesch and Benesch (6) have recently proposed that binding of 2,3-DPG by deoxygenated hemoglobin may affect cation permeability.

An approach to the study of the physiologic role of 2,3-DPG is suggested by the work of Manyai and Varady (7), who found that human erythrocytes could be selectively depleted of the compound by the action of the bisulfite ion, leaving ATP content and glycolysis intact. The object of the studies reported here has been to initiate an investigation of the effects of the bisulfite ion on the cation content and metabolism of human red blood cells. As will be shown, this anion has a profound, reversible influence on the movements of both $\mathrm{Na}$ and $\mathrm{K}$ ions. Its capacity to deplete red cells of 2,3DPG has been confirmed. The data suggest that it is the reducing property of bisulfite which mediates its effects on cation flux and that the permeability changes are independent of the levels of 2,3-DPG.

\section{METHODS}

The following reagents were obtained from commercial sources: All enzymes for analysis of glucose, G6P, FDP, triose-P, 3-PG, 2,3-DPG, pyruvate, lactate, and ATP from Boehringer Mannheim Corp., New York; lactate, pyruvate, 3-PG, 2,3-DPG, NAD, NADH, NADP, GSH, and GSSH from Calbiochem, Los Angeles, Calif.; methylene blue, 
inosine, ATP, FDP, and G6P from Sigma Chemical Co., St. Louis, Mo.; and metabisulfite salts from Allied Chemical Corp., Morristown, N. J.

The standard oxidation-reduction potentials of some of the reagents used in these studies are shown in Table I. Reducing systems in this notation have more negative potentials than oxidizing systems, and all values are expressed in relation to the standard hydrogen electrode.

Blood from hematologically normal human adults was drawn into syringes rinsed with heparin $(50 \mathrm{mgm} / \mathrm{ml})$, and the cells were washed 2 or 3 times by centrifugation in a solution which contained $\mathrm{NaCl} 145 \mathrm{~mm}, \mathrm{KCL} 5 \mathrm{~mm}$, glycylglycine $20 \mathrm{~mm}$, and glucose $10 \mathrm{~mm}(\mathrm{pH} 7.5)$. The cells were suspended in various incubation media whose compositions are detailed with the results, and the suspensions were placed in a $37^{\circ} \mathrm{C}$ water bath with constant shaking. Samples were removed from the incubation flasks from time to time for the determination of $\mathrm{Na}, \mathrm{K}, \mathrm{Cl}, \mathrm{P}_{1}$, and for the preparation of perchloric acid extracts. In most of the studies the hematocrits of the suspensions ranged from 6 to 12 volumes $\%$. Hematocrits were determined in quadruplicate by the microhematocrit method.

$\mathrm{Na}$ and $\mathrm{K}$ were determined by flame photometry (Instrumentation Laboratory, Inc., Watertown, Mass.) on cells washed 3 times with $280 \mathrm{mOsm} \mathrm{MgCl}_{2}$ following removal from the incubation mixtures. Cell chloride and water content were measured after centrifugation of the suspensions at $20,000 \mathrm{~g}$ in specially constructed lucite tubes which funneled the cells into a column whose trapped plasma was ascertained by inulin $-{ }^{14} \mathrm{C}$ studies to be $2.5 \%$. Extraction of the cells for measurement of chloride was done by diluting $0.5 \mathrm{ml}$ of packed cells to $10 \mathrm{ml}$ with distilled water. To $1 \mathrm{ml}$ of the resulting hemolysate was added $0.5 \mathrm{ml}$ of a solution containing $0.7 \mathrm{~N} \mathrm{ZnSO}_{4}$ and $0.25 \mathrm{~N} \mathrm{H}_{2} \mathrm{SO}_{4} .1 \mathrm{ml}$ of $0.75 \mathrm{~N}$ $\mathrm{NaOH}$ was then added, followed by $3 \mathrm{ml}$ of distilled water. The precipitated protein was then removed by centrifugation. $1 \mathrm{ml}$ of the protein-free supernatant was then mixed with $1 \mathrm{ml}$ of water and $0.5 \mathrm{ml}$ of a solution containing $0.5 \mathrm{~N} \mathrm{HNO}_{3}$ and $50 \%$ acetic acid. A drop of gelatin was added. Chloride was then measured on a Buchler-Cotlove chloridometer (Buchler Instruments, Inc., Fort Lee, N. J.). Cell water was determined by drying $0.1-0.3 \mathrm{~g}$ of packed cells to constant weight in a $70^{\circ} \mathrm{C}$ vacuum oven.

Determinations of glucose, ATP, G6P, FDP, triose-P, 3-PG, 2,3-DPG, and pyruvate were done by the enzymatic methods detailed by Lowry, Passoneau, Hasselberger, and Schulz (9). A fluorometer was used (Model A3, Farrand Optical Co., Inc., New York). Lactate was determined

TABLE I

Standard Oxidation-Reduction Potentials (8)

\begin{tabular}{lc}
\hline \multicolumn{1}{c}{ Reaction } & $\mathrm{E}_{0^{\prime}}$ at $\mathrm{pH} 7.0$ \\
\hline & $v$ \\
Ascorbate $+\mathrm{H}^{+} \rightarrow$ Dehydroascorbate & 0.166 \\
$2 \mathrm{Cysteine} \longrightarrow$ Cystine & -0.340 \\
$\mathrm{NADH}+\mathrm{H}^{+} \longrightarrow$ NAD & -0.320 \\
$2 \mathrm{GSH} \longrightarrow$ GSSG $^{+}$ & -0.340 \\
$\mathrm{H}_{2} \mathrm{O}_{2} \longrightarrow \mathrm{O}_{2}$ & 0.295 \\
Methylene blue $\longrightarrow$ Leuko methylene blue & 0.011 \\
Lactate $\longrightarrow$ Pyruvate & -0.185 \\
(Bi) sulfite $\longrightarrow$ Sulfate & -0.454 \\
\hline
\end{tabular}

See text for explanation. spectrophotometrically with lactic dehydrogenase and a glycine-hydrazine buffer system as described in Bergmeyer (10). Extracts for these determinations were prepared by injecting rapidly 1 volume of cell suspension into 2 volumes of ice-cold $15 \%$ perchloric acid. The resulting supernatant was neutralized with crystals of $\mathrm{K}_{2} \mathrm{CO}_{3}$, using phenol red as an indicator. Recovery of all the intermediates from such extracts was quantitative and was not affected by the inclusion in the incubation media of $10 \mathrm{~mm}$ metabisulfite or $20 \mathrm{~mm}$ pyruvate.

Inorganic phosphate was determined on the supernatant from the cell suspensions by the automated method of Gitelman, Kukolj, and Welt (11).

\section{RESULTS}

Solutions of sodium bisulfite $\left(\mathrm{NaHSO}_{3}\right)$, when evaporated to dryness, yield crystals of sodium metabisulfite $\left(\mathrm{Na}_{2} \mathrm{~S}_{2} \mathrm{O}_{5}\right)$, and it is in this form that the salt is commercially available (12). Consequently, the concentration of this agent in the charts and tables is expressed in terms of the molarity of the metabisulfite salt (abbreviated $\mathrm{S}_{2} \mathrm{O}_{5}$ ) used in preparing the incubation media.

Fig. 1 shows that immediatley on exposure to bisulfite the cells begin to accumulate $\mathrm{Na}$ and to lose $\mathrm{K}$. 2,3-DPG levels start to fall. The rate of change of $\mathrm{Na}$ and $\mathrm{K}$ appears to be independent of the 2,3-DPG concentration. Less than $1 \%$ hemolysis occurred during the $6 \mathrm{hr}$ incubation. Fig. 2 demonstrates that the net fluxes of $\mathrm{Na}$ and $\mathrm{K}$ over a $4 \mathrm{hr}$ period increase with increasing concentrations of metabisulfite over a concentration range from 0 to $10 \mathrm{~mm}$. The effects of bisulfite and ouabain on $\mathrm{Na}$ and $\mathrm{K}$ flux are additive, and therefore independent of one another. Bisulfite thus affects permeability by some mechanism other than interference with the ATP-dependent Na-K pump which is completely inhibited by this concentration of ouabain (13). The stimulatory effect of bisulfite on lactate formation is also shown in Fig. 2. It is known that increasing the concentration of cell $\mathrm{Na}$ will stimulate glycolysis in human erythrocytes by raising the rate of active cation transport (14). The failure of ouabain to normalize lactate production in cells treated with bisulfite suggests that the stimulation of glycolysis by this anion is not due solely to the rise in cell Na. Finally, Fig. 2 shows the response of the cell 2,3-DPG content to graded concentrations of metabisulfite and the lack of effect of ouabain on the 2,3-DPG pool.

Table II indicates the effects of a $4 \mathrm{hr}$ incubation with $10 \mathrm{~mm}$ metabisulfite on cell $\mathrm{Na}, \mathrm{K}, \mathrm{Cl}$, and water content. The changes in medium $\mathrm{pH}$ are also shown. This exposure to bisulfite results in the disappearance of at least $90 \%$ of the cell 2,3-DPG (Figs. 1 and 2). $\mathrm{K}$ loss exceeds $\mathrm{Na}$ gain, and yet accumulation of $\mathrm{Cl}$ and water takes place. The decrease in undetermined anions $\left(X^{-}\right)$ is greater than what would be expected on the basis of the $\mathrm{pH}$ changes alone. Reference to the data of Van Slyke, $\mathrm{Wu}$, and McLean (15) indicates that a drop in 

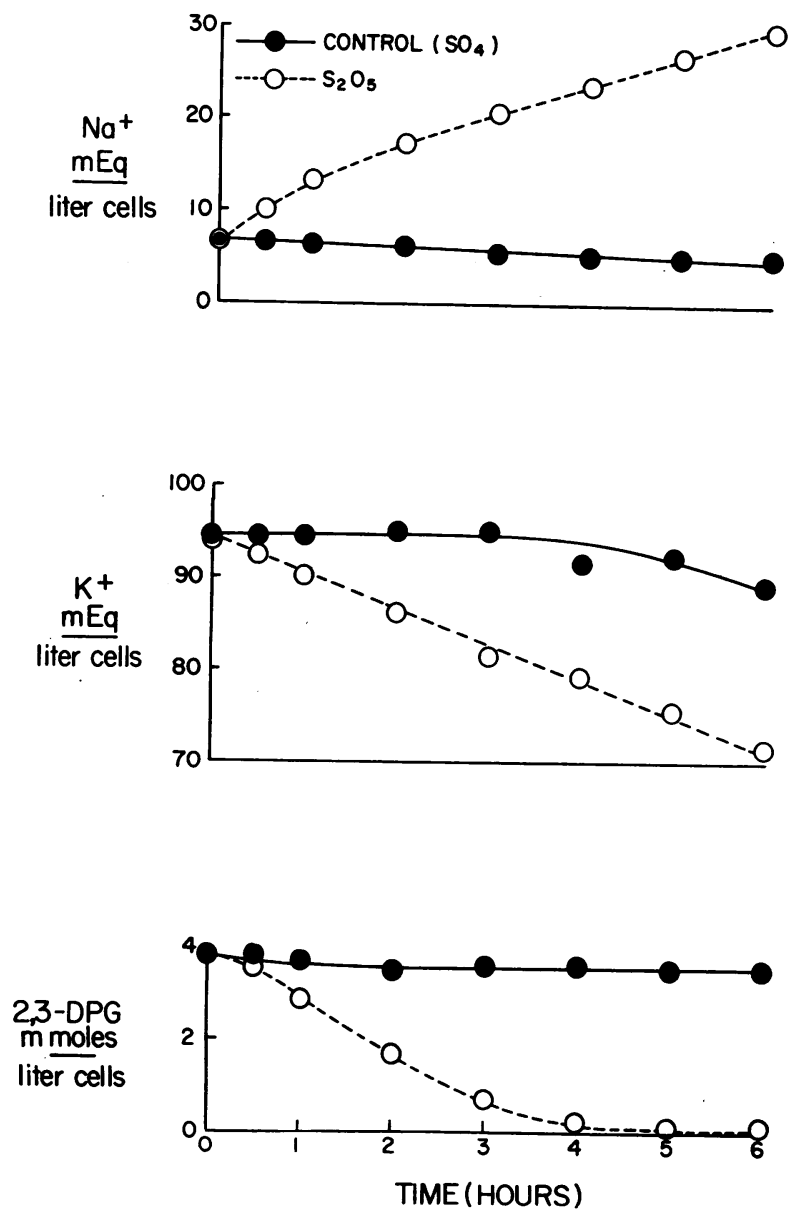

Figure 1 The effect of metabisulfite on the cell content of $\mathrm{Na}, \mathrm{K}$, and 2,3-DPG as a function of time. Cells washed in the manner described were suspended at a hematocrit of 10 volumes $\%$ in solutions containing $\mathrm{NaCl} 130 \mathrm{~mm}, \mathrm{KCl}$ $5 \mathrm{~mm}$, glycylglycine $20 \mathrm{~mm}$, glucose $10 \mathrm{~mm}$, and either

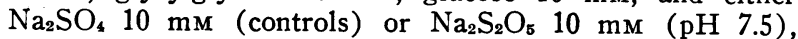
and placed at $37^{\circ} \mathrm{C}$. Samples were removed from the suspension at the time intervals shown and analyzed for $\mathrm{Na}, \mathrm{K}$, and 2,3-DPG.

$\mathrm{pH}$ of 0.2 units from an initial value of 7.50 should decrease the anion equivalency of hemoglobin by no more than $12 \mathrm{mEq} /$ liter cells. The somewhat larger changes noted in the presence of the bisulfite ion are presumably due to the release of inorganic phosphate, a slowly diffusible anion (16) from the cell 2,3-DPG. Guest and Rapoport (3) estimated that the 2,3-DPG present in normal human red blood cells accounts for 30 anion equivalents per $\mathrm{kg}$ cell water.

The reversibility of the effect of bisulfite on cation flux is shown in Fig. 3. In these experiments the initial exposure of cells to bisulfite was done with $\mathrm{K}$ as the principal cation in the medium. In this circumstance $\mathrm{Na}$ accumulation and $\mathrm{K}$ loss were prevented, although 2,3 -
DPG depletion occurred. The cells were then washed free of bisulfite and placed in high $\mathrm{Na}$ media. With no bisulfite no $\mathrm{Na}$ accumulation occurs, even though the cells have been nearly depleted of 2,3-DPG by the preincubation. Furthermore, the capacity of the depleted cells to respond to the permeability effects of a reexposure to bisulfite is not altered by their reduced 2,3DPG content. The stimulatory effect of bisulfite on lactate production is lost, however, in the 2,3-DPG de-

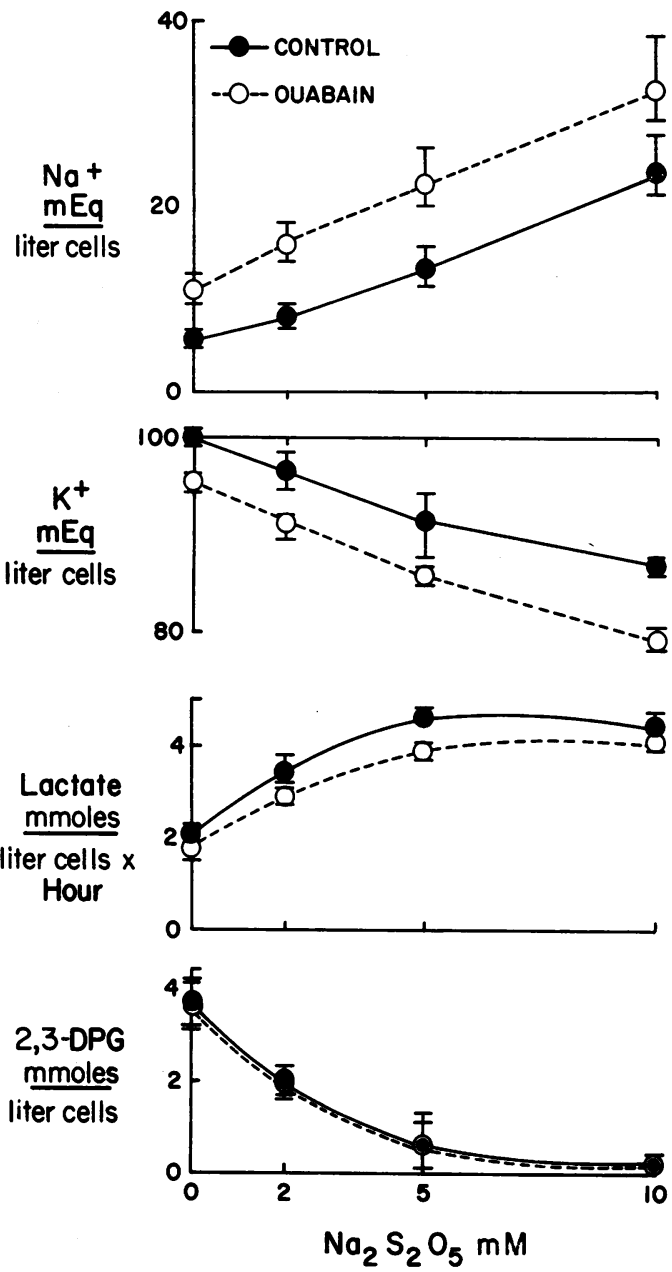

FIgURE 2 The effects of a $4 \mathrm{hr}$ exposure to various concentrations of $\mathrm{Na}_{2} \mathrm{~S}_{2} \mathrm{O}_{5}$ on cell $\mathrm{Na}, \mathrm{K}$, lactate, and 2,3-DPG in the presence and absence of ouabain $0.1 \mathrm{~mm}$. The incubation solutions all contained $\mathrm{NaCl} 130 \mathrm{~mm}, \mathrm{KCl} 5 \mathrm{~mm}$, glycylglycine $20 \mathrm{~mm}$, glucose $10 \mathrm{~mm}$. $\mathrm{Na}_{2} \mathrm{~S}_{2} \mathrm{O}_{5}$ was included in the concentrations indicated on the abscissa, and the solutions were brought to equal $\mathrm{Na}$ concentrations with $\mathrm{NaCl}$. All were adjusted to $\mathrm{pH}$ 7.5. The values for $\mathrm{Na}, \mathrm{K}$, and 2,3-DPG were obtained after $4 \mathrm{hr}$ incubation at $37^{\circ} \mathrm{C}$. Lactate production was linear with time between 1 and 4 $\mathrm{hr}$, and the rates were calculated from lactate concentrations measured at $1,2 \frac{1}{2}$, and $4 \mathrm{hr}$. The mean and range for three experiments are given. 
TABLE II

Effects of $10 \mathrm{mM}$ Metabisulfite on Movements of $\mathrm{Na}, \mathrm{K}$, and $\mathrm{Cl}^{*}$

\begin{tabular}{|c|c|c|c|c|}
\hline \multirow[b]{3}{*}{$\mathrm{Na}^{+}$} & \multicolumn{2}{|c|}{ Initial value } & \multicolumn{2}{|c|}{ Change in $4 \mathrm{hr}$} \\
\hline & Control & $\mathrm{S}_{2} \mathrm{O}_{3}$ & Control & $\mathrm{S}_{2} \mathrm{O}_{6}$ \\
\hline & $11.3 \pm 1.0$ & $12.8 \pm 2.5$ & $-1.2 \pm 0.4$ & $+15.1 \pm 0.8$ \\
\hline $\mathrm{K}^{+}$ & $157.0 \pm 4.2$ & $160.0 \pm 4.3$ & $+1.0 \pm 2.5$ & $-21.5 \pm 1.0$ \\
\hline $\mathrm{Cl}$ & $97.1 \pm 5.6$ & $92.2 \pm 9.7$ & $0.0 \pm 1.0$ & $+15.0 \pm 4.8$ \\
\hline$X^{-}$ & $71.3 \pm 2.7$ & $81.2 \pm 11.1$ & $-0.3 \pm 2.7$ & $-22.0 \pm 4.8$ \\
\hline $\mathrm{H}_{2} \mathrm{O}$ & $64.1 \pm 0.5$ & $62.3 \pm 0.2$ & $-0.3 \pm 0.3$ & $+3.3 \pm 0.4$ \\
\hline Medium pH & $7.50 \pm 0.02$ & $7.50 \pm 0.02$ & $-0.13 \pm 0.03$ & $-0.18 \pm 0.02$ \\
\hline
\end{tabular}

The incubation media for this experiment were calculated to contain $\mathrm{NaCl} 130 \mathrm{mM}, \mathrm{KCl} 5 \mathrm{~mm}$, glycylglycine $20 \mathrm{~mm}$, glucose $10 \mathrm{mM}$, and either $\mathrm{Na}_{2} \mathrm{SO}_{4} 10 \mathrm{~mm}$ (control) or $\mathrm{Na}_{2} \mathrm{~S}_{2} \mathrm{O}_{5} 10 \mathrm{mM}\left(\mathrm{S}_{2} \mathrm{O}_{5}\right)$. Measured chloride concentrations in the media after suspension of cells at a hematocrit of 10 were: control, $137 ; \mathrm{S}_{2} \mathrm{O}_{5}, 134 \mathrm{mEq} /$ liter. Cells were separated for analysis of $\mathrm{Na}$, K, $\mathrm{Cl}$, and water content within $20 \mathrm{~min}$ of suspension in the media and again after a $4 \mathrm{hr}$ incubation at $37^{\circ} \mathrm{C}$.

* Ion concentrations are given in $\mathrm{mEq} /$ liter of cell water. $X^{-}$was calculated as the difference between $\mathrm{Na}+\mathrm{K}$ and $\mathrm{Cl}$. Water content is given as per cent wet weight. The means and standard deviations of four experiments are given.

pleted cells. Bisulfite was also found to induce the permeability change to $\mathrm{Na}$ and $\mathrm{K}$ in cells rendered free of 2,3-DPG by substrate depletion, as shown in Table III.

The data presented thus far have shown that when cells are bathed in a high $\mathrm{Na}$ medium, bisulfite, like ouabain, can cause accumulation of $\mathrm{Na}$ and loss of $\mathrm{K}$.
Such net downhill movements of ions could be due either to inhibition by bisulfite of some active transport mechanism not affected by ouabain (17) or to an increase in the movement of $\mathrm{Na}$ and $\mathrm{K}$ through "leak" channels. Table IV shows that under suitable conditions bisulfite can facilitate the downhill movements of $\mathrm{Na}$ and $\mathrm{K}$ in
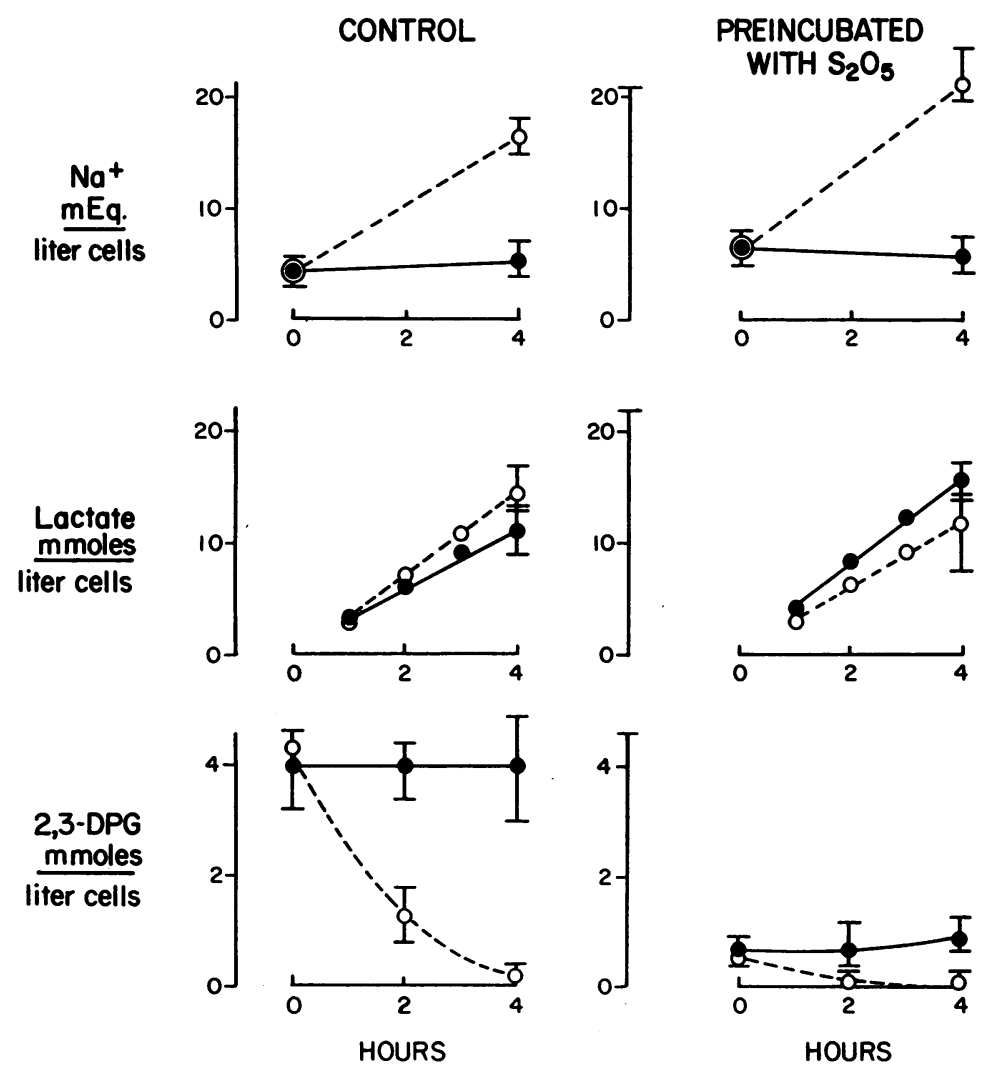

FIGURE 3 The reversibility of the bisulfite effect on $\mathrm{Na}$, lactate, and 2,3-DPG. Fresh red cells were divided into 2 lots and preincubated for $3 \mathrm{hr}$ at $37^{\circ} \mathrm{C}$ in solutions which contained $\mathrm{KCl} 135 \mathrm{~mm}$, glycylglycine $20 \mathrm{~mm}$, glucose 10 $\mathrm{mM}$, and either $\mathrm{Na}_{2} \mathrm{SO}_{4} 10 \mathrm{~mm}$ or $\mathrm{Na}_{2} \mathrm{~S}_{2} \mathrm{O}_{3}$ $10 \mathrm{~mm}$ ( $\mathrm{pH} 7.5$ ). Both groups of cells were then washed with a solution which contained $\mathrm{KCl} 150 \mathrm{~mm}$, glycylglycine $20 \mathrm{~mm}$, and glucose $10 \mathrm{~mm}$. Each group of cells was then divided into two parts and incubated for a further $4 \mathrm{hr}$ at $37^{\circ} \mathrm{C}$ in one of two solutions whose compositions were identical to the preincubation media except that all but $5 \mathrm{~mm}$ of the $\mathrm{KCl}$ was replaced by $\mathrm{NaCl}$. $\mathrm{Na}, \mathrm{K}, 2,3-\mathrm{DPG}$, and lactate were measured at the intervals shown on the abscissae. Open circles and dashed lines represent cells which were exposed to $\mathrm{S}_{2} \mathrm{O}_{5}$ during the second incubation. Closed circles and solid lines represent control cells exposed to $\mathrm{SO}_{4}$. Cells preincubated with $\mathrm{SO}_{4}$ had a normal content of 2,3-DPG (left hand panel), while cells preincubated with $\mathrm{S}_{2} \mathrm{O}_{5}$ began the second incubation with low levels of this compound (right hand panel). The mean and range for four experiments are given. 
TABLE III

Influence of Substrate Depletion on the Bisulfite Effect

\begin{tabular}{lccccc}
\hline \multirow{2}{*}{$\begin{array}{c}m E q \text { or mmoles } \\
\text { liter cells }\end{array}$} & \multicolumn{2}{c}{ No glucose } & & \multicolumn{2}{c}{ Glucose } \\
\cline { 2 - 3 } \cline { 6 - 6 } \cline { 5 - 6 } & control & $\mathrm{S}_{2} \mathrm{O}_{6}$ & & control & $\mathrm{S}_{2} \mathrm{O}_{3}$ \\
\hline $\mathrm{Na}$ at $4 \mathrm{hr}$ & 9.8 & 26.4 & & 6.5 & 22.4 \\
$\mathrm{~K}$ at $4 \mathrm{hr}$ & 89.2 & 62.0 & & 92.0 & 82.5 \\
$2,3-\mathrm{DPG}$ at & $<0.1$ & $<0.1$ & & $<0.1$ & $<0.1$ \\
$\quad 0$ and $4 \mathrm{hr}$ & & & & \\
$\mathrm{ATP}$ at $4 \mathrm{hr}$ & $<0.05$ & $<0.05$ & & 1.1 & 0.3 \\
$\begin{array}{l}\text { Triose-P }+\mathrm{FDP} \\
\text { at } 4 \mathrm{hr}\end{array}$ & $<0.01$ & $<0.01$ & & 0.12 & 0.73 \\
& & & & & \\
\hline
\end{tabular}

Fresh cells were preincubated for $24 \mathrm{hr}$ at $37^{\circ} \mathrm{C}$ in a solution which contained $\mathrm{KCl} 150 \mathrm{~mm}$, glycylglycine $20 \mathrm{~mm}$ ( $\mathrm{pH} 7.5)$, and penicillin (1000 units) in the presence and absence of glucose $10 \mathrm{~mm}$. The cells were then washed in isotonic $\mathrm{KCl}$ and incubated for a further $4 \mathrm{hr}$ in high sodium media in the presence and absence of metabisulfite as detailed in the legend of Fig. 1, except that glucose was withheld from the cells which had been preincubated without glucose.

the reverse direction, thus ruling out an appreciable effect on active transport. In this study the cells are loaded with $\mathrm{Na}$ and depleted of $\mathrm{K}$ by preincubation with bisulfite in a high $\mathrm{Na}$ medium. The cells are then washed free of bisulfite and placed in high $\mathrm{K}$ media in the presence and absence of bisulfite. The cells which are reexposed to bisulfite lose $\mathrm{Na}$ and gain $\mathrm{K}$ faster than the

TABLE IV

Effects of $10 \mathrm{mM}$ Metabisulfite on Na Loss and K Gain

\begin{tabular}{|c|c|c|c|c|c|}
\hline & & \multicolumn{2}{|c|}{ Initial value } & \multicolumn{2}{|c|}{ Change in $4 \mathrm{hr}$} \\
\hline \multicolumn{2}{|c|}{ Experiment } & Control & $\mathrm{S}_{2} \mathrm{O}_{6}$ & Control & $\mathrm{S}_{2} \mathrm{O}_{3}$ \\
\hline & & \multicolumn{2}{|c|}{$m E q / l i t e r$ cells } & \multicolumn{2}{|c|}{$m E q /$ liter cells } \\
\hline \multirow[t]{2}{*}{1} & $\mathrm{Na}$ & 25.9 & 25.6 & -2.3 & -6.4 \\
\hline & $\mathrm{K}$ & 80.0 & 79.7 & +2.4 & +6.1 \\
\hline \multirow[t]{2}{*}{2} & $\mathrm{Na}$ & 25.5 & 25.9 & -1.3 & -6.0 \\
\hline & $\mathrm{K}$ & 81.8 & 82.3 & +1.9 & +6.4 \\
\hline \multirow[t]{2}{*}{3} & $\mathrm{Na}$ & 25.7 & 25.7 & -2.1 & -6.9 \\
\hline & $\mathrm{K}$ & 78.8 & 79.0 & +1.7 & +4.5 \\
\hline
\end{tabular}

The $\mathrm{Na}$ content of fresh cells was raised by preincubation for $3 \mathrm{hr}$ at $37^{\circ} \mathrm{C}$ in a solution which consisted of $\mathrm{NaCl} 130 \mathrm{~mm}$, $\mathrm{KCl} 5 \mathrm{~mm}, \mathrm{Na}_{2} \mathrm{~S}_{2} \mathrm{O}_{5} 10 \mathrm{~mm}$, glycylglycine $20 \mathrm{~mm}$, glucose $10 \mathrm{~mm}$, and ouabain $0.1 \mathrm{~mm}(\mathrm{pH} \mathrm{7.5)}$. The cells were then washed 4 times with a solution identical to the preincubation medium, except that the $\mathrm{Na}_{2} \mathrm{~S}_{2} \mathrm{O}_{5}$ was replaced by $\mathrm{NaCl}$ $15 \mathrm{~mm}$. The washed cells were placed in a solution which contained $\mathrm{KCl} 135 \mathrm{~mm}$, glycylglycine, glucose, and ouabain in the concentrations used for the preincubation, and either $\mathrm{K}_{2} \mathrm{SO}_{4} 10 \mathrm{~mm}$ (control) or $\mathrm{K}_{2} \mathrm{~S}_{2} \mathrm{O}_{5} 10 \mathrm{~mm}\left(\mathrm{~S}_{2} \mathrm{O}_{5}\right)$. The cell $\mathrm{Na}$ and $\mathrm{K}$ concentrations were then determined at the beginning and end of a $4 \mathrm{hr}$ incubation at $37^{\circ} \mathrm{C}$. Blood from three different donors was used. controls. Since bisulfite facilitates the net downhill flux of $\mathrm{Na}$ and $\mathrm{K}$ in both directions across the cell membrane, it must be acting on passive rather than active transfer mechanisms.

The effects of bisulfite could be modified by various oxidizing agents which by themselves had no influence on $\mathrm{Na}$ and $\mathrm{K}$ movements, 2,3-DPG levels, or lactate production. Fig. 4 shows that in the presence of increasing concentrations of pyruvate the bisulfite effect on $\mathrm{Na}$ and $\mathrm{K}$ flux is reduced, and the stimulation of lactate produc-
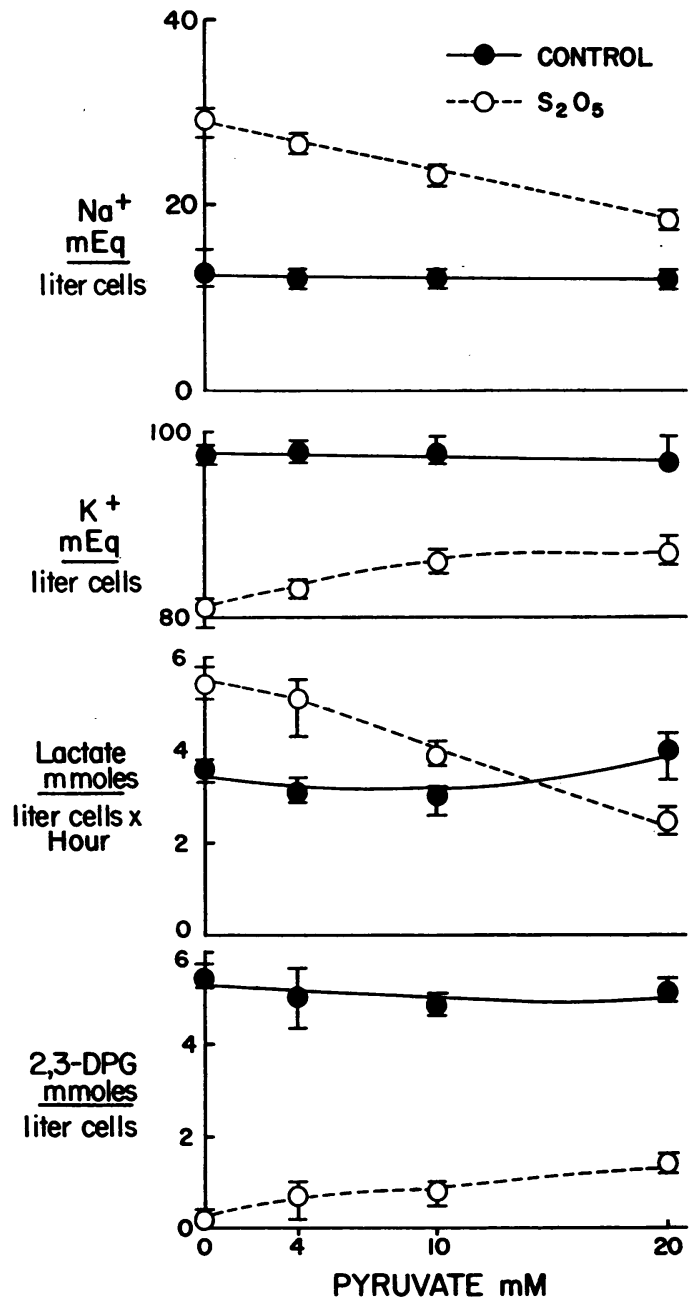

Figure 4 The influence of pyruvate in reducing the effect of $10 \mathrm{~mm} \mathrm{Na} \mathrm{S}_{2} \mathrm{O}_{6}$ on $\mathrm{Na}, \mathrm{K}$, lactate and 2,3-DPG over a $4 \mathrm{hr}$ incubation at $37^{\circ} \mathrm{C}$. All solutions contained $\mathrm{NaCl} 110$ $\mathrm{mM}, \mathrm{KCl} 5 \mathrm{mM}$, glycylglycine $20 \mathrm{~mm}$, glucose $10 \mathrm{~mm}$, ouabain $0.1 \mathrm{~mm}$, and either $\mathrm{Na}_{2} \mathrm{SO}_{4} 10 \mathrm{mM}$ or $\mathrm{Na}_{2} \mathrm{~S}_{2} \mathrm{O}_{6} 10$ mM. Pyruvate was added in the concentrations shown on the abscissa, and the solutions were brought to equal $\mathrm{Na}$ concentrations with $\mathrm{NaCl}(\mathrm{pH}$ 7.5). Cell $\mathrm{Na}, \mathrm{K}$, lactate production, and 2,3-DPG were measured as described in the legend to Fig. 2. The mean and range for three experiments are shown. 
tion is reversed, although 2,3-DPG depletion continues to take place. It is apparent from these data that substantial reversal of the effects of bisulfite required nearly equimolar concentrations of pyruvate. The action of bisulfite on $\mathrm{Na}$ and $\mathrm{K}$ movements could also be partially reversed by matching concentrations of oxidized glutathione or hydrogen peroxide. In contrast, methylene blue, which has a much lower oxidizing potential than pyruvate (Table I), completely obiliterated the effect of bisulfite on Na-K flux in relatively small concentrations (Fig. 5). It is known from the studies of Weed, Eber, and Rothstein (18) that this dye causes increased permeability of red cells to $\mathrm{Na}$ and $\mathrm{K}$, and this is confirmed by the data in Fig. 5. Of note, however, is the observation that in the presence of micromolar concentrations of methylene blue, $10 \mathrm{~mm}$ metabisulfite exerts no effect on $\mathrm{Na}$ and $\mathrm{K}$ permeability, although it retains most of its action on 2,3-DPG. The influences of pyruvate and methylene blue on cell $\mathrm{Na}$ and $\mathrm{K}$ content could not have been due to stimulation of the ATP-dependent Na-K pump, inasmuch as the experiments
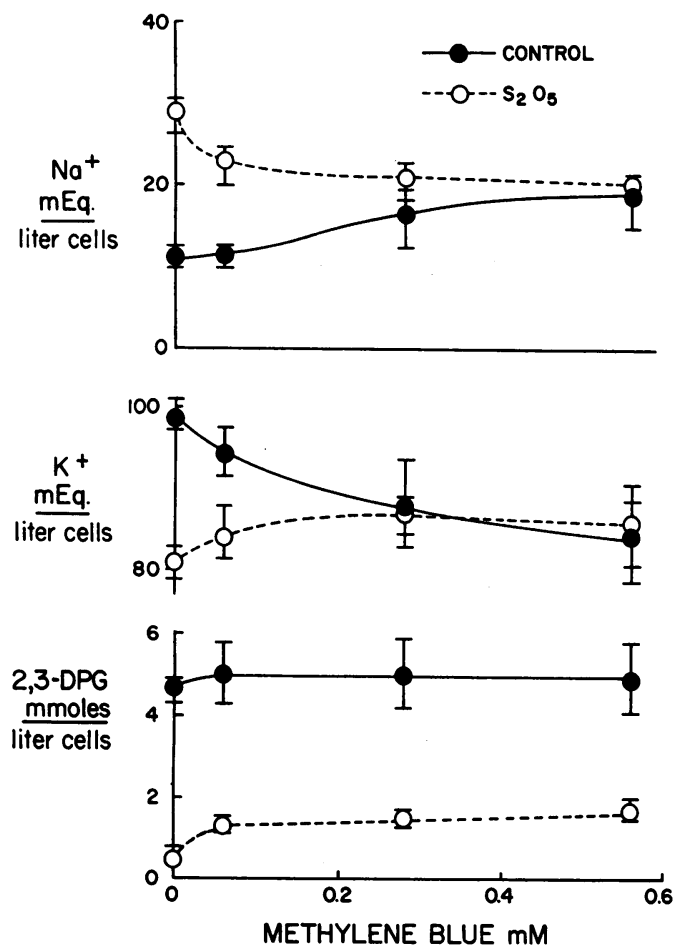

FIGURE 5 The influence of methylene blue in reducing the effect of $10 \mathrm{~mm} \mathrm{Na} \mathrm{Na}_{2} \mathrm{~S}_{5}$ on $\mathrm{Na}, \mathrm{K}$, and 2,3-DPG content over a $4 \mathrm{hr}$ incubation at $37^{\circ} \mathrm{C}$. All solutions contained $\mathrm{NaCl}$ $130 \mathrm{~mm}, \mathrm{KCl} 5 \mathrm{~mm}$, glycylglycine $20 \mathrm{~mm}$, glucose $10 \mathrm{~mm}$, ouabain $0.1 \mathrm{~mm}$, and either $\mathrm{Na}_{2} \mathrm{SO}_{4} 10 \mathrm{~mm}$ or $\mathrm{Na}_{2} \mathrm{~S}_{2} \mathrm{O}_{5} 10$ $\mathrm{mm}$ ( $\mathrm{pH}$ 7.5). Methylene blue was added in the concentrations shown on the abscissa. Cell $\mathrm{Na}, \mathrm{K}$, and 2,3-DPG content were measured at $4 \mathrm{hr}$. The mean and range for three experiments are shown.
TABLE V

Reversal of the Permeability Effects of $10 \mathrm{mM}$ Metabisulfite by Ethacrynic Acid*

\begin{tabular}{lrrrrr}
\hline & \multicolumn{2}{c}{ No additions } & & \multicolumn{2}{c}{ Ethacrynic acid } \\
\cline { 2 - 3 } \cline { 5 - 6 } Experiment & Control & $\mathrm{S}_{2} \mathrm{O}_{6}$ & & Control & $\mathrm{S}_{2} \mathrm{O}_{5}$ \\
\hline $1 \mathrm{Cell} \mathrm{Na}$ & 11.4 & 26.5 & & 16.0 & 16.8 \\
$\mathrm{~K}$ & 92.2 & 79.7 & & 84.9 & 86.6 \\
$2,3-\mathrm{DPG}$ & 5.6 & 1.9 & & 5.4 & 1.9 \\
$2 \mathrm{Cell} \mathrm{Na}$ & 7.2 & 23.6 & & 12.5 & 13.4 \\
$\mathrm{~K}$ & 99.7 & 87.4 & & 90.2 & 94.6 \\
$2,3-\mathrm{DPG}$ & 4.0 & 0.6 & 3.9 & 0.8 \\
$3 \mathrm{Cell} \mathrm{Na}$ & 5.9 & 20.3 & & 10.5 & 10.2 \\
$\mathrm{~K}$ & 106.4 & 92.4 & 94.1 & 97.1 \\
$2,3-\mathrm{DPG}$ & 4.7 & 0.4 & 4.7 & 0.6 \\
\hline
\end{tabular}

The incubation media for this experiment were the same as for the study in Table II. The effect of adding ethacrynic acid $1 \mathrm{~mm}$ to the media ( $\mathrm{pH} 7.5$ ) is shown.

* Cell Na, K (mEq/liter cells) and 2,3-DPG (mmoles/liter cells) were determined after $4 \mathrm{hr}$ incubation at $37^{\circ} \mathrm{C}$.

shown in Figs. 4 and 5 were conducted with ouabain $0.1 \mathrm{~mm}$ in the media. Ethacrynic acid, a diuretic known to inhibit the unidirectional efflux of sodium from red cells (17), was found to be capable of counteracting the effects of $10 \mathrm{~mm}$ metabisulfite on $\mathrm{Na}$ and $\mathrm{K}$ flux (Table $\mathrm{V})$. Furosemide (1 $\mathrm{mm}$ ) had a similar but less marked effect.

Studies directed toward elucidating the metabolic effects of bisulfite are shown in Fig. 6. Here the concentrations of various intermediates in the glycolytic sequence are given in cells incubated with sulfate, bisulfite,

TABLE VI

Glucose Consumption and Lactate Production in Cells Exposed to $10 \mathrm{~mm}$ Metabisulfite

\begin{tabular}{ccc}
\hline Experiment & Glucose cousumption & Lactate production \\
\hline & mmoles/liter cells & mmoles/liter cells \\
1 Control & 3.5 & 7.3 \\
$\mathrm{~S}_{2} \mathrm{O}_{5}$ & 8.3 & 13.9 \\
$2 \mathrm{Control}_{\mathrm{S}_{2} \mathrm{O}_{5}}$ & 3.2 & 6.4 \\
& 10.3 & 16.8 \\
$3 \mathrm{Control}$ & & \\
$\mathrm{S}_{2} \mathrm{O}_{5}$ & 4.2 & 8.8
\end{tabular}

Incubation solutions contained $\mathrm{NaCl} 130 \mathrm{~mm}, \mathrm{KCl} 5 \mathrm{~mm}$, glycylglycine $20 \mathrm{~mm}$, glucose $3 \mathrm{~mm}$, and either $\mathrm{NaCl} 15 \mathrm{~mm}$ (control) or $\mathrm{Na}_{2} \mathrm{~S}_{2} \mathrm{O}_{5} 10 \mathrm{~mm}\left(\mathrm{~S}_{2} \mathrm{O}_{5}\right)$. Initial $\mathrm{pH}$ was 7.5. The incubation was carried out for $4 \mathrm{hr}$ at $37^{\circ} \mathrm{C}$. The total glucose consumed and lactate produced during this period were divided by the hematocrit (25-30 volumes $\%$ ) to obtain the values in mmoles/liter cells. 
and pyruvate. Sulfate, the oxidation product of bisulfite, is known from the studies of Rizzo and Eckel (19) to cause a fall in hexose monophosphate and a rise in fructose diphosphate in red blood cells. The data in Fig. 6 suggest that the stimulation of lactate production by bisulfite is associated with similar alterations in the hexose phosphate levels and that pyruvate acts to counter the bisulfite effect by reversing these changes. One interpretation of the data in Fig. 6 is that both sulfate and bisulfite stimulate glycolysis by increasing the rate of the phosphofructokinase step.

The stimulation of lactate production by bisulfite is matched by a rise in glucose consumption, as shown in Table VI. The rise in glucose/lactate ratio noted with bisulfite can be accounted for if the carbons which ac-

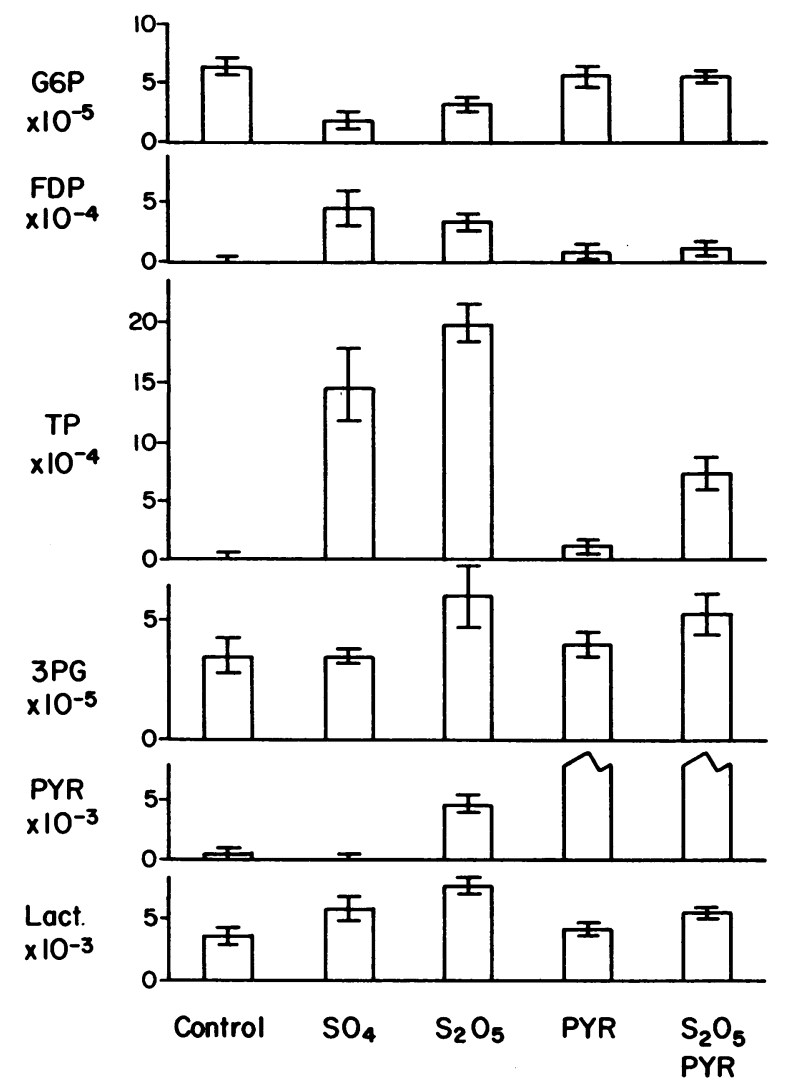

FIGURE 6 The levels of various glycolytic intermediates in cells incubated at $37^{\circ} \mathrm{C}$ in the presence of sulfate, bisulfite, and pyruvate. All solutions contained $\mathrm{NaCl} 120 \mathrm{~mm}, \mathrm{KCl}$ $5 \mathrm{~mm}$, glycylglycine $20 \mathrm{~mm}$, and glucose $10 \mathrm{~mm}$. $\mathrm{Na}_{2} \mathrm{SO}_{4} 10$ $\mathrm{mm}, \mathrm{Na}_{2} \mathrm{~S}_{2} \mathrm{O}_{5} 10 \mathrm{~mm}$, and pyruvate $10 \mathrm{~mm}$ were added to the media as shown on the abscissa, all solutions were brought to equal $\mathrm{Na}$ concentrations with $\mathrm{NaCl}$, and the $\mathrm{pH}$ was adjusted to 7.5. Analyses were performed on perchloric acid extracts as described in the text. All the values shown were obtained on cell suspensions which had been incubated at $37^{\circ} \mathrm{C}$ for $2 \mathrm{hr}$. The levels of the intermediates are expressed in moles per liter of cells. Means and standard deviations from four experiments are given.
TABLE VII

Effects of $4 \mathrm{Hr}$ Exposure to Metabisulfite on ATP, 2,3$D P G$, Pyruvate, and Phosphate*

\begin{tabular}{lrr}
\hline & \multicolumn{1}{c}{ Control } & \multicolumn{1}{c}{$\mathrm{S}_{2} \mathrm{O}_{5}$} \\
\hline ATP at $4 \mathrm{hr}$ & $1.3 \pm 0.1$ & $1.2 \pm 0.1$ \\
2,3-DPG: Change in & $-0.5 \pm 0.3$ & $-4.5 \pm 0.5$ \\
$\quad 4 \mathrm{hr}$ & & \\
Pyruvate: Change & $+0.3 \pm 0.2$ & $+4.6 \pm 0.5$ \\
$\quad$ in $4 \mathrm{hr}$ & & \\
$\mathrm{P}_{\mathrm{i}}$ : Change in $4 \mathrm{hr}$ & $+2.4 \pm 0.2$ & $+6.3 \pm 0.4$ \\
\hline
\end{tabular}

These results were obtained on the incubations presented in Fig. 6 at 4 hr.

* All values are expressed in mmoles/liter cells. The means and standard deviations for four experiments are given.

cumulate in the cell as FDP and triose-P (Fig. 6) are taken into account, as shown by the following calculation, using experiment 1 as an example: The ratio of glucose consumption to lactate production under control conditions is $3.5 / 7.3=0.48$. With bisulfite the ratio rises to $8.3 / 13.9=0.60$. The accumulation of 0.45 mmoles FDP and 2.09 mmoles triose-P/liter of bisulfite-stimulated cells (Fig. 6) accounts for the consumption of 1.50 mmoles glucose which is not converted to lactate. Subtraction of this quantity from the glucose consumed gives a glucose/lactate ratio of $6.8 / 13.9=0.49$.

The 2,3-DPG which disappears in the presence of bisulfite is almost quantitatively recoverable as pyruvate and inorganic phosphate, as shown in Table VII. The relatively minor effect of bisulfite on ATP levels is also shown. These data are entirely confirmatory of the results of Manyai and Varady (7).

\section{DISCUSSION}

The studies reported here demonstrate that in the presence of bisulfite ions, human red blood cells undergo an increase in passive permeability to $\mathrm{Na}$ and $\mathrm{K}$, a reduction in 2,3-DPG content, and an increase in the rate of conversion of glucose to lactate. The effects on cation flux are independent of the 2,3-DPG level and the rate of glycolysis (Fig. 3, Table III).

The implications of these experiments contrast with the conclusions reached by Gardos $(4,5)$ who found that the rate of $\mathrm{K}$ loss from iodoacetate-treated cells rose abruptly once 2,3-DPG stores became exhausted. $\mathrm{He}$ proposed that the outward movement of $\mathrm{K}$ is in some way limited by the activity of 2,3-DPG phosphatase within the cell and that normal $\mathrm{K}$ permeability is therefore dependent on the presence of sufficient concentrations of 2,3-DPG to act as substrate for this enzyme. Gardos also found that provided ample 2,3-DPG was present, bisulfite ions would delay the onset of the rapid $\mathrm{K}$ loss which occurs when red cells are incubated with calcium ions, iodoacetate, and adenosine. $\mathrm{He}$ at- 
tributed this effect to the capacity of bisulfite to activate 2,3-DPG phosphatase (7). In the present studies bisulfite was found to increase the rate of $\mathrm{K}$ loss from the cells, and its effects did not seem to be related to the availability of 2,3-DPG.

Whether the permeability effects of bisulfite are due to direct action on the membrane or to alteration on intracellular events is not clear. Sulfate, which affects the cellular concentrations of G6P, FDP, and triose-P in a manner similar to bisulfite (Fig. 6) had no effect on $\mathrm{Na}$ or $\mathrm{K}$ flux. The effects of bisulfite on cation movements were not modified by fluoride (5 $\mathrm{mm}$ ), high medium phosphate $(20 \mathrm{~mm})$, adenosine, or conversion of hemoglobin to methemoglobin by preincubation with nitrite. Maneuvers designed to increase the ratio of reduced to oxidized pyridine nucleotides within the cell, such as incubation with $20 \mathrm{~mm}$ xylitol (20) or $20 \mathrm{~mm}$ lactate (21), produced no effect on net $\mathrm{Na}$ and $\mathrm{K}$ movements over a $4 \mathrm{hr}$ period. Reducing agents less potent than bisulfite (Table I) such as ascorbic acid, mercaptoethanol, and reduced glutathione were equally inactive in this regard.

The reversal of the bisulfite-induced permeability changes by various oxidizing agents (Figs. 4 and 5 ) nevertheless suggests that it is the reducing property of this anion which is important in its effects on cation movements. Methylene blue and pyruvate are known to divert glucose metabolism through the pentose phosphate pathway (22), and a possibility worth investigation is that reoxidation of $\mathrm{NADPH}$ is instrumental in the effects of these agents in protecting the cells from the effects of the bisulfite ion. If methylene blue and pyruvate were acting simply to oxidize the bisulfite in the medium, one would expect that the influence of this anion on 2,3-DPG content would be obliterated pari passu with the effect on permeability. In the case of pyruvate, a substantial reduction to lactate might be anticipated, and yet pyruvate retards the rate of lactate accumulation in suspensions of cells incubated with bisulfite (Fig. 4).

The action of ethacrynic acid in obliterating the permeability effects of bisulfite may be related to the reactivity of this diuretic with thiol groups (23). If the action of bisulfite were due to reduction of disulfide bonds, then the effect of ethacrynic acid might be mediated by attachment of the diuretic to the resulting sulfhydryl moieties. An alternative possibility is that ethacrynic acid acts as an oxidizing agent.

The pertinence of these observations to the specific effects on $\mathrm{K}$ permeability of high fluoride concentrations (24), lead salts, triose reductone, and other agents recently reviewed by Passow (25) is not certain, inasmuch as bisulfite appears to affect $\mathrm{Na}$ movements as well as those of $\mathrm{K}$. The experiments reported here do suggest, however, that under appropriate conditions the permeability of the cell to alkali metal cations can be profoundly and reversibly influenced by changes in state of oxidation. Further studies directed toward identification of the functional groups on the membrane which are responsible for the alterations in cation flux may contribute to an understanding of the determinants of normal $\mathrm{Na}$ and $\mathrm{K}$ permeability in human red blood cells.

\section{ACKNOWLEDGMENT}

This work was supported by U. S. Public Health Service Grant No. AM 11356.

\section{REFERENCES}

1. Pizer, L. I. 1962. Phosphoglycerate mutase. In The Enzymes. P. D. Boyer, H. Lardy, and K. Myrback, editors. Academic Press Inc., New York. 6: 179.

2. Sutherland, E. W., T. Z. Pasternak, and C. F. Cori. 1949. The mechanism of action of phosphoglucomutase and phosphoglyceric acid mutase. J. Biol. Chem. 179: 501.

3. Guest, G. M., and S. Rapoport. 1939. Role of acidsoluble phosphorus compounds in red blood cells. Amer J. Dis. Child. 58: 1072.

4. Gardos, G. 1966. The mechanism of ion transport in human erythrocytes. I. The role of 2,3-diphosphoglyceric acid in the regulation of potassium transport. Acta Biochim. Biophys. Acad. Sci. Hung. 1: 139.

5. Gardos, G. 1967. Studies on potassium permeability changes in human erythrocytes. Experientia (Basel). 23: 19.

6. Benesch, R., and R. E. Benesch. 1968. Oxygenation and ion transport in red cells. Science. 160: 83 .

7. Manyai, S., and Z. Varady. 1958. Elektiver Abbau der 2,3-Diphosphoglyzerinsaure in Roten Blutkorperchen. Acta Physiol. Acad. Sci. Hung. 14: 103.

8. Long, C., editor. 1961. Biochemist's Handbook. D. Van Nostrand Company, Inc., Princeton. 93.

9. Lowry, O. H., J. V. Passonneau, F. X. Hasselberger, and D. W. Schulz. 1964. Effect of ischemia on known substrates and cofactors of the glycolytic pathway in brain. $J$. Biol. Chem. 239: 18.

10. Bergmeyer, H. U. 1963. editor. Methods of Enzymatic Analysis. Academic Press Inc., New York.

11. Gitelman, H. J., S. Kukolj, and L. G. Welt. 1968. The influence of the parathyroid glands on the hypercalcemia of experimental magnesium depletion in the rat. J. Clin. Invest. 47: 118 .

12. Wood, C. W., and A. K. Holliday. 1960. Inorganic Chemistry. Butterworth \& Co., Ltd., London.

13. Gill, T. J., and A. K. Solomon. 1959. Effect of ouabain on sodium flux in human red cells. Nature. 183: 1127.

14. Parker, J. C., and J. F. Hoffman. 1967. The role of membrane phosphoglycerate kinase in the control of glycolytic rate by active cation transport in human red blood cells. J. Gen. Physiol. 50: 893.

15. Van Slyke, D. D., H. Wu, and F. C. McLean. 1923 Studies of gas and electrolyte equilibria in the blood. J. Biol. Chem. 56: 765.

16. Vestergaard-Bogind, B. 1963. The transport of phosphate ions across the human red cell membrane. Biochim. Biophys. Acta. 66: 93.

17. Hoffman, J. F. 1966. The red cell membrane and the transport of sodium and potassium. Amer. J. Med. 41: 666. 
18. Weed, R., J. Eber, and A. Rothstein. 1961. The effects of primaquine and other related compounds on the red blood cell membrane. $\mathrm{I}$. $\mathrm{Na}$ and $\mathrm{K}$ permeability in normal human cells. J. Clin. Invest. 40: 130.

19. Rizzo, S. C., and R. E. Eckel. 1966. Control of glycolysis in human erythrocytes by inorganic phosphate and sulfate. Amer. J. Physiol. 211: 429.

20. Asakura, T., K. Adachi, S. Minakami, and H. Yoshikawa. 1967. Non-glycolytic sugar metabolism in human erythrocytes. I. Xylitol metabolism. J. Biochem. (Tokyo) 62: 184.

21. Rieber, E. E., N. S. Kosower, and E. R. Jaffe. 1968. Reduced nicotinamide adenine dinucleotide and the reduction of oxidized glutathione in human erythrocytes. $J$. Clin. Invest. 47: 66.
22. Szeinberg, A., and P. A. Marks. 1961. Substances stimulating glucose catabolism by the oxidative reactions of the pentose phosphate pathway in human erythrecytes. J. Clin. Invest. 40: 914.

23. Duggan, D. E., and R. M. Noll. 1965. Effects of ethacrynic acid and cardiac glycosides upon a membrane adenosinotriphosphatase of renal cortex. Arch. Biochem. Biophys. 109: 388.

24. Eckel, R. E. 1958. Potassium exchange in human erythrocytes. I. General aspects of the fluoride effect. $J$. Cell. Comp. Physiol. 51: 81.

25. Passow, H, 1964. Ion and water permeability of the red blood cell. In The Red Blood Cell. C. Bishop and D. M. Surgenor, editors. Academic Press Inc., New York. 